\title{
Children with special needs in health: challenges of the single health system in the $21^{\text {st }}$ century
}

\author{
Criança com necessidades especiais de saúde: desafios do sistema único de saúde no século XXI \\ Niños con necesidades especiales en salud: desafíos del sistema único de salud en el siglo XXI
}

\section{Camilla Ferreira Catarino Barreiros' ORCID: 0000-0003-3975-3117}

Maria Auxiliadora de Souza Mendes Gomes" ORCID: 0000-0001-5908-1763

Saint Clair do Santos Mendes Júnior" ORCID: 0000-0002-1554-943X

'Instituto de Puericultura e Pediatria Martagão Gesteira. Rio de Janeiro, Rio de Janeiro, Brazil.

"Instituição Nacional de Saúde da Mulher, da Criança e do Adolescente Fernandes Figueira. Rio de Janeiro, Rio de Janeiro, Brazil.

How to cite this article: Barreiros CFC, Gomes MASM, Mendes Jr SCS. Children with special needs in health: challenges of the single health system in the 21st century. Rev Bras Enferm. 2020;73(Suppl 4):e20190037. doi: http://dx.doi.org/10.1590/0034-7167-2019-0037

\section{Corresponding author:}

Camilla Ferreira Catarino Barreiros E-mail:enfcamillacatarino@yahoo.com.br

EDITOR IN CHIEF: Dulce Barbosa ASSOCIATE EDITOR: Italo Rodolfo Silva

Submission: 03-13-2019

Approval: 07-25-2020

\section{ABSTRACT}

Objective: Reflect on the gaps in the care of Children with Special Needs in Health that demand complex clinical care with dependence on technological support for the maintenance of life, in the Unified Health System. Methods: This is a reflection study based on recent policies and literature related to the theme. Discussion: Despite the advances achieved with the Unified Health System with regard to access to health services and the expansion of Primary Care, with the aim of reorienting health, it can be said that the health care model for CSHCN in Brazil is still centered on the hospital and medical knowledge. Final considerations: There are gaps in the policies for children aimed at the new paediatric profile, and little is discussed about its implications for the Unified Health System.

Descriptors: Child; Unified Health System; Public Policy; Health Care; Integrality in Health; Chronic disease.

\section{RESUMO}

Objetivo: Refletir sobre as lacunas no atendimento às Crianças com Necessidades Especiais de Saúde que demandam cuidados clínicos complexos com dependência de suporte tecnológico para manutenção da vida, no Sistema Único de Saúde. Métodos: Trata-se de um estudo de reflexão pautado nas políticas e literatura recentes relacionadas ao tema. Discussão: Apesar dos avanços conquistados com o Sistema Único de Saúde no que diz respeito ao acesso aos serviços de saúde e à ampliação da Atenção Básica, com o objetivo de reorientar a saúde, pode-se afirmar que o modelo de atenção à saúde às CRIANES no Brasil ainda é centrado no hospital e no saber médico. Considerações finais: Observam-se lacunas nas políticas para a criança destinadas ao novo perfil de pediatria, e pouco se discute sobre suas implicações para o Sistema Único de Saúde.

Descritores: Criança; Sistema Único de Saúde; Política Pública; Atenção à Saúde; Integralidade em Saúde; Doença Crônica.

\section{RESUMEN}

Objetivo: Reflejar las lagunas en la atención a los Niños con Necesidades Especiales de Salud, cuidados clínicos complejos de esa demanda con dependencia de la ayuda tecnológica para el mantenimiento de la vida, en el Sistema Único de Salud. Métodos: Se trata de un estudio basado en la reflexión de la política y de la literatura recientes relacionadas al tema. Discusión: Aunque los avances conquistados con el Sistema Único de Salud acerca del acceso a los servicios médicos y a la ampliación de la atención básica, con el objetivo para reorientar la salud, pueden ser afirmados que el modelo de la atención a la salud a CRIANES en Brasil todavía se centra en el hospital y el "saber médico". Consideraciones finales: Se observan lagunas en las políticas para el niño destinadas al nuevo perfil de la pediatría, y poco se discute sobre sus implicaciones para el Sistema Único de Salud.

Descriptores: Niño; Sistema Único de Salud; Política Pública; Atención a la salud; Integralidad en Salud; Enfermedad Crónica. 


\section{INTRODUCTION}

As a consequence of the epidemiological transition process, there was an important reduction in infant mortality from acute and infectious diseases. The situation is different in relation to chronic and degenerative diseases, which become increasingly common in childhood and which, in most cases, require some type of technology to maintain life ${ }^{(1)}$. This event takes place in developed and developing countries, in which both access to advanced health technologies has improved and enabled sophisticated treatments, previously unknown. Technological changes coupled with specific public policies to reduce child morbimortality had an important relevance in reducing these rates due to acute and infectious diseases.

Within this context, a new paediatrics is born, with the role of children who demand special health care, of a temporary or permanent nature, with numerous medical diagnoses, continuous dependence on health services and an important role of the multidisciplinary team in view of their clinical fragility. This new clientele was first named in 1998 by the Maternal and Health Children Bureau, in the USA, as Children with Special Health Care Needs $(\mathrm{CSHCN})^{(2)}$. This concept is not only centered on chronic illness, but also on the child's needs, with regard to their life and needs, as well as the greater use of health-related services ${ }^{(3)}$. In Brazil, they were called Children with Special Needs in Health (CSHCN), with additional aggravating factors being social vulnerability and the absence of specific public policies on this group ${ }^{(4)}$.

Several Brazilian studies indicate that CSHCN present a type of care classified into six groups, namely: (1) care in relation to development: includes those with neuromuscular disease that need psychomotor rehabilitation and social support; (2) technological care: those that use life-sustaining devices, such as gastrostomy, tracheostomy, semi-implanted catheter, etc..; (3) medication care: there are the drug addicts, that is, those who make continuous use of medications, such as cardiotonics, anticonvulsants, antiretrovirals etc.; (4) habitual modified care: those that need adaptive technologies in daily care and in activities of daily living to get around, eat, get dressed, when using the toilet etc.; (5) mixed care: there is a combination of one or more demands, excluding technological; and (6) clinically complex care: there is a combination of all of the above including the management of life support technologies ${ }^{(5)}$.

It is necessary to consider the need to discuss and reflect on the lack of public policies aimed at CSHCN. The management of this group requires a higher number of care than that required by other children, with emphasis on the group of children who demand clinically complex care. Families face constant pilgrimages to health services in search of specialized treatment, in addition to needing a multi-professional care network capable of contributing to their empowerment process until discharge ${ }^{(6)}$.

These new demands can have important impacts in terms of health planning: (1) prolonged hospitalizations, therefore difficulties and impediments to hospital discharge; (3) worse use of public resources; (4) reduction of beds available for the treatment of acute diseases, among others; and (5) fragmentation of public policies of the Unified Health System (SUS) that support this child and their family after discharge.
This study proposes a reflexive analysis about the gaps in the care of CSHCN that demand complex clinical care with dependence on technological support for maintaining life in SUS.

\section{PUBLIC POLICIES OF GREAT IMPACT ON CHILD HEALTH}

This topic exposes the main policies developed in the area of child health in search of finding actions for $\mathrm{CSHCN}$, in a timeline, even if indirectly.

The formulation of programmatic proposals, in the assistance of maternal and child health, started more evident from the 1970s with the creation of the Maternal and Child Health Program (PSMI), the first official program focused on the health area of child. Its actions were basically focused on prenatal care, control of home birth work, attention to the puerperium and actions to promote children's health. In the same period, associated with the improvement of social conditions in the country, there was a beginning, albeit timid, in the fall in infant mortality ${ }^{(7)}$.

The consequences of the PSMI were: the creation of the Comprehensive Health Care Program for Women (PAISM) and the Comprehensive Child Health Care Program (PAISC). This focused on the following activities: (1) breastfeeding and food assistance; (2) assistance and control of diarrheal diseases; (3) assistance and control of respiratory diseases; (4) immunization; and (5) monitoring growth and development ${ }^{(7)}$.

Since then, perinatal care and infectious and parasitic diseases have become a priority in the discussion of public policies in the area of child health, through various ordinances and publications of the Ministry of Health.

In the early 1990s, the Ministry of Health released the Community Health Agents Program (PACS), created in 1991 ${ }^{(8)}$; and in 1994, the Family Health Program (PSF) ${ }^{(8)}$. Although they are not specifically strategies aimed at child health, both indirectly favored preventive actions and control of preventable diseases, as well as strengthened the restructuring of the counter-hegemonic model, focused on health promotion and community participation. Although they are not specifically strategies aimed at child health, both indirectly favored preventive actions and control of preventable diseases, as well as strengthened the restructuring of the counter-hegemonic model, focused on health promotion and community participation. Even though its creation occurred in a different context from the current one, it is known that, nowadays, it has a preponderant role in assisting children who need clinically complex care, especially in the support network for children and their families in the home environment.

In 1995, the Baby Friendly Hospital Initiative (BFHI) emerged, which strives to strengthen humanized childbirth, breastfeeding and, consequently, reduce diseases due to preventable causes ${ }^{(9)}$. In 1996, Integrated Care for Childhood Illnesses (AIDIP) emerged, which focused on the rapid reduction of infant mortality from preventable causes. During this period, several health professionals received training on the proper management of childhood prevalent diseases, especially respiratory diseases and diarrhoea ${ }^{(7)}$.

Since then, there has been a new, progressive reality related to children's health. Infant mortality declines significantly, breastfeeding rates increase, diarrheal diseases are controlled, malnutrition is no longer a public health problem, and chronic diseases become a priority ${ }^{(10)}$. 
In 1998, the Support Program for the Implementation of State Hospital Reference Systems for Assistance to High-Risk Pregnant Women was structured. During this period, specific resources were allocated for the purchase of materials and equipment as well as for the training of professionals, with the objective of integrating and improving the quality of prenatal care and the link between prenatal care and childbirth ${ }^{(7)}$.

In 2000, the Ministry of Health (MS) launched, through Ministerial Ordinance No. 693, the Humanized Care Standard for Low Weight New-Borns - the Kangaroo Method, in consideration of the large number of premature births and low birth weight; and the fact that the main causes of infant deaths originate in the perinatal period (about 40\%). In the same year, the National Program for the Humanization of Prenatal and Birth was created and implemented, through Ordinance No.569, based on guaranteeing the right to citizenship, therefore, access, by pregnant women and new-borns, to health care in the prenatal, childbirth, puerperium and neonatal periods, in both low and high risk pregnancies, ensuring comprehensive care ${ }^{(7)}$.

Since the beginning of discussions on child health in Brazil, the preventative actions towards acute diseases and support for labor and child-birth have always been priorities, because they involved the main causes of infant mortality in the country, at that time. However, even after the epidemiological transition, it can be seen that efforts were maintained in perinatal disease, as the main focus, probably because it is the biggest cause of infant mortality, in addition to having a major investment in the study of new technologies. On the other hand, all this investment is parallel to the expressive increase in the number of CSHCN in Brazil, especially those that demand clinically complex care, that is, coming from intensive care beds, which encounter numerous obstacles to de-hospitalization.

In 2004, the Ministry of Health included, in the agenda of childcare priorities, 13 lines of care, which are: (1) women's health actions ensuring qualified and humanized care. This axis involves women's reproductive health, ensuring that this process occurs in a planned and healthy way; (2) humanized and qualified care for pregnant women and new-borns (NB), which implies reorganization of the health system in order to guarantee access, coverage and quality in perinatal care; (3) neonatal screening and foot testing; (4) encouraging breastfeeding; (5) encouraging and qualifying the monitoring of growth and development; (6) healthy eating and prevention of overweight and childhood obesity; (7) combating malnutrition and anaemia/deficiencies; (8) immunization; (9) attention to prevalent childhood diseases; (10) attention to oral health; (11) attention to mental health; (12) the prevention of accidents, violence/abuse and child labor; (13) care for children with disabilities ${ }^{(7)}$.

Even with the elaboration of 13 lines of care in the area of child health, none of them was directed to CSHCN who demand clinically complex care. The line of care for children with disabilities incorporated some types of CSHCN, but not those dependent on life-sustaining technologies and those who need other demands after hospital discharge.

\section{PUBLIC POLICIES FOR CSHCN}

In view of the historical context presented on child health, it is natural to look for policies that support CSHCN. It is inevitable to reflect: within this reality, there are children dependent on technological resources that, in most cases, are not available at home. For this reason, this topic will address public policies and ordinances that, although aimed at chronic patients, reach CSHCN even if indirectly. It is noteworthy that, in the search for this reference, terminologies that considered CSHCN were used, however the term "chronic patient" or "chronic illness" is the most used in the documents of the Ministry of Health.

In 2001, the first ordinance (GM/MS No. 1,531) was instituted, which allowed patients with progressive muscular dystrophy to use non-invasive mechanical ventilation at home, under the care of specific teams, financed by SUS. However, the beneficiaries were only carriers of this pathology. In June 2008, through Ordinance GM/MS No. 1,370, regulated by Ordinance SAS/MS No. 370 , of July 2008, the Ministry of Health expanded the list of pathologies eligible for registration in the program, but still insufficiently for the demand, as it excluded frequent causes of permanent respiratory failure - and even today it remains restricted to neuromuscular diseases.

In 2011, the Brazilian government published the strategic action plan to tackle chronic non-communicable diseases, which aimed to prepare the country to face and stop, in the following ten years, Chronic Non-Communicable Diseases (NCDs). Although it is an important initiative, CSHCN or strategies in the process of "de-hospitalization" are not addressed in any of its axes.

Also in 2011, through Ordinance No. 2,527, the Ministry of Health redefines Home Care $(\mathrm{HC})$ within the scope of the Unified Health System. One of the central axes of HC is "de-hospitalization", providing hospital discharge with continuity of treatment at home, defining the role of the caregiver, reducing the risks of hospital infection associated with prolonged hospitalization and the autonomy of the patient and their family in the caution. However, this ordinance does not bring crucial tools for the "de-hospitalization" of children who demand complex clinical care, that is, when the child needs technological support for the maintenance of life, such as a mechanical ventilator, the discharge does not happen.

Another relevant document, published by the MS, is the Guidelines for Comprehensive Care for People with Rare Diseases: published in 2014, it proposes to organize the care given to children with rare diseases, within the scope of SUS, through the definitions of the attributions of each level of care, including the specialized network. Although they have an important contribution, they do not address issues related to the "de-hospitalization" of children with special needs.

In 2015, by Decree n 1,130, of August 5, the National Policy for Comprehensive Child Health Care (PNAISC) was instituted, which has seven strategic axes: (1) humanized and qualified care for pregnancy; (2) breastfeeding and healthy eating; (3) promoting and monitoring growth and development; (4) comprehensive care for children with diseases prevalent in childhood and with chronic diseases; (5) comprehensive care for child victims of violence; (6) health care for children with disabilities or in specific and vulnerable situations; (7) surveillance and prevention of infant, foetal and maternal death ${ }^{(11)}$.

The axis that includes comprehensive care for children with diseases prevalent in childhood and with chronic illness has, in its article 10, three actions necessary to reach the axis: (I) Integrated 
Management for Childhood IIIness (IMCI); (II) construction of guidelines and lines of care; (III) fostering care and home care ${ }^{(11)}$.

Only in 2015, with PNAISC, a more advanced debate started, involving CSHCN dependent on technologies and other services.

\section{DISCUSSION}

Despite the advances achieved with SUS, with regard to access to health actions and services, and the significant expansion of Primary Care through the Family Health Strategy, with the aim of reorienting the way health was being produced, it can be said that the health care model of CSHCN, prevalent in Brazil, is still fragmented, biologistic and mechanistic, centered on the hospital and medical knowledge.

With the brief history presented, there is a crisis in the hegemonic medical model, which does not meet the new population demands for better quality and comprehensive and continuous care, especially with regard to children who need complex clinical care and depend on a technological support for hospital discharge. Numerous obstacles hinder this process, from technical support to an integrated and well-articulated health care network.

Through the aforementioned timeline on public policies aimed at CSHCN, it is clear that, in Brazil, this advance did not occur together with technological advances; and this reality has consequences for health services, especially for the specialized network.

A study published in 2012, on the profile of paediatric hospitalizations in four federal hospitals in Rio de Janeiro, portrayed this reality well. Of the four units studied, three had more than $50 \%$ of hospitalizations were children with chronic diseases; this analysis took place within a year ${ }^{(12)}$. The process of "de-hospitalization" of these children has several obstacles that prolong hospitalization of children with clinical stability, able to continue treatment at home. The discharge, for these children, brings a series of benefits, especially the reduction of risks that the hospital environment offers. This signals the need to discuss a new health care model.

Nowadays, a "shared" care model between hospital care and Primary Care is already being debated, through the new model of home care. This regulates and guarantees human resources necessary for the continuity of care in the home environment for patients who need different technologies, be it medication, manipulation of tubes, ostomies, medication administration or manipulation of catheters. However, when the child's need involves the use of some ventilatory support discharge does not occur ${ }^{(13)}$.

It is necessary to clarify that the "de-hospitalization" process does not impact the reduction of hospital costs, but optimizes them, that is, it ensures that the resource is better used, considering that the hospital environment brings risks to the patient ${ }^{(13)}$.
It is worth mentioning that the countless technological advances have generated other demands in relation to the structure, profile and organization of the child health care network: before focusing on acute child-care, today it needs investment in the management of children with chronic degenerative diseases. In view of all the strategies developed, none directly prioritizes CSHCN, whose "de-hospitalization" process does not occur. This reality favors the increase in prolonged hospitalizations, decreasing the number of beds in the SUS for the treatment of diseases in acute condition.

A study sought to compare the assistance to CSHCN in Brazil and Canada, since, in both countries, the health system is universal and free for all citizens. Even with these common characteristics, the authors described numerous differences in the care of the CSHCN. In Canada, family caregivers have, through the health system, a range of institutional programs that ensure the wellbeing of the child and the comfort, safety and rest of the family. In Brazil, the benefit of continued provision is the only financial resource that families in situations of poverty can turn to. Family members rely more on the solidarity network than on the social network. It is common for these families to resort to the Childhood and Youth Court of their municipalities to receive greater financial support in order to offer the minimum care necessary for home care, however this is not always met ${ }^{(14)}$.

The first strategy identified for this progress is to change the care model for these children in Brazil. In Canada, for example, the care model is social and not biomedical like the Brazilian ${ }^{(14)}$.

The elaboration of guidelines and lines of care more structured and specific to the CSHCN is also an important path to be pursued in order to organize the health system through the training of professionals and the establishment of quality standards. However, in fact, the promotion of care and home care is at the heart of the discussion of this problem. Greater financial investment is required for these CSHCNs after discharge, ensuring that, at home, both the child and their family will receive due support, either with the necessary technologies available, or with a more structured health network, with strengthening of the network reference and counter-reference. Legislation that supports children and their families is fundamental, but that alone is not enough: it is essential to guarantee the enforcement of this right.

\section{FINAL CONSIDERATIONS}

There are gaps in the policies for children aimed at the new paediatric profile, and there is little debate about its implications for SUS. The discussion on the topic is indispensable for new advances in the area. This signals to managers the need to restructure the Brazilian health system in the area of child health, which is still predominantly hegemonic.

\section{REFERENCES}

1. Reis KMN, Alves GV, Barbosa TA, Lomba GO, Braga PP. A vivência da família no cuidado domiciliar à criança com necessidades especiais de saúde. Cienc Enferm. 2017;23(1):45-55. doi: 10.4067/S0717-95532017000100045.

2. McPherson MG, Arango P, Fox H, Lauver C, McManus M, Newachek PW, et al. A new definition of children with special health care needs. Pediatrics. 1998;102(1);137-41. 
3. Data Resource Center for Child and Adolescent Health (DRC). The Child and Adolescent Health Measurement Iniciative (CAHMI). National Survey of children's Health (NSCH) [Internet]. 2019. [cited 16 jul 2019. Available from: http://childhealthdata.org

4. Neves ET, Cabral IE. Cuidar de crianças com necessidades especiais de saúde: desafios para as famílias e enfermagem pediátrica. Rev Eletr Enferm. [Internet]. 2009[cited 2019 Jul 16];11(3):527-38. Available from: http://www.fen.ufg.br/revista/v11/n3/v11n3a09.htm

5. Góes FGB, Cabral IE. Discourses on discharge care for children with special healthcare needs. Rev Bras Enferm. 2017;70(1):154-61. doi: 10.1590/0034-7167-2016-0248

6. Neves ET, Cabral IE. Empoderamento da mulher cuidadora de crianças com necessidades especiais de saúde. Texto Contexto Enferm. 2008;17(3):552-60. doi: 10.1590/S0104-07072008000300017

7. Ministério da Saúde (BR), Secretaria de Atenção à Saúde, Área Técnica de Saúde da Criança e Aleitamento Materno. Gestões e gestores de políticas públicas de atenção à saúde da criança: 70 anos de história [Internet]. Brasília: Ministério da Saúde; (Série I. História da Saúde); 2011 [cited 2018 Nov 19]. 80 p. Available from: http://bvsms.saude.gov.br/bvs/publicacoes/70_anos_historia_saude_crianca.pdf

8. Ministério da Saúde (BR), Secretaria de Atenção à Saúde, Departamento de Atenção Básica. Memórias da saúde da família no Brasil [Internet]. Brasília: Ministério da Saúde; (Série I. História da Saúde no Brasil); 2010 [cited 2018 Nov 19]. 144 p. Available from: http://bvsms. saude.gov.br/bvs/publicacoes/memorias_saude_familia_brasil.pdf

9. Lopes SS, Laignier MR, Primo CC, Leite FMC. Baby-Friendly hospital initiative: evaluation of the ten steps to successful breastfeeding. Rev Paul Pediatr. 2013;31(4):488-93. doi: 10.1590/S0103-05822013000400011

10. Moreira MCN, Gomes R, Sá MRC. Doenças crônicas em crianças e adolescentes: uma revisão bibliográfica. Ciênc Saúde Coletiva. 2014;19(7):2083-94. doi: 10.1590/1413-81232014197.20122013

11. Ministério da Saúde (BR). Política nacional de atenção integral à saúde da criança: orientação para a implementação [Internet]. Brasília: Ministério da Saúde; 2018 [cited 2018 Nov 19]. 180 p. Available from: http://www.saude.pr.gov.br/arquivos/File/Politica_Nacional_de_ Atencao_Integral_a_Saude_da_Crianca_PNAISC.pdf

12. Duarte JG, Gomes SC, Pinto MT, Gomes MASM. Perfil dos pacientes internados em serviços de pediatria no município do Rio de Janeiro: mudamos? Physis. 2012;22(1):199-214. doi: 10.1590/S0103-73312012000100011

13. Ministério da Saúde (BR). Melhor em casa: segurança do hospital no conforto do seu lar [Internet]. Brasília: Ministério da Saúde; 2013 [cited 2018 Nov 19]. 19 p. Available from: http://189.28.128.100/dab/docs/portaldab/documentos/manual_instrucao_melhor_casa.pdf

14. Leal JR, Cabral IE, Perreault M. Experiência Brasil-Canadá no cuidado social e na saúde da criança com necessidades especiais: aproximações e distanciamentos. Interfaces Brasil/Canadá Rev Bras Est Can. 2010; (11):95-119. doi: 10.15210/interfaces.v10i1.7074 